\title{
Multiple system atrophy
}

INSERM

\section{Source}

INSERM. (1999). Orphanet: an online rare disease and orphan drug data base. Multiple system atrophy. ORPHA:102

Multiple system atrophy (MSA) is a neurodegenerative disorder characterized by autonomic failure (cardiovascular and/or urinary), parkinsonism, cerebellar impairment and corticospinal signs with a median survival of 6-9 years. 